\title{
THE RELATIONSHIP BETWEEN SERUM LIPIDS AND THE ELEC- TROPHORETIC PATTERN, WITH PARTICULAR REFERENCE TO PATIENTS WITH PRIMARY BILIARY CIRRHOSIS
}

\author{
By HENRY G. KUNKEL AND EDWARD H. AHRENS, JR. \\ (From the Hospital of The Rockefeller Institute for Medical Research, New York City)
}

(Received for publication July 8, 1949)

One of the major characteristics of the serum of patients with chronic biliary obstruction is a marked elevation in the serum lipids. This elevation is primarily due to an increase in the phospholipid fraction although the cholesterol and neutral fat are also high (1). The phospholipid has been shown to act as a natural emulsifying agent to hold the other lipids in a clear solution (2). The presence of clear serum along with marked abnormalities in total lipid made the sera from these patients an ideal source material for studying the relationship of lipid changes to alterations in electrophoretic patterns. Analyses of these sera indicated a correlation between the total lipid level and the area of the beta globulin peaks determined electrophoretically.

\section{MATERIALS AND METHODS}

Sera were obtained from 11 patients in the fasting state and were subjected to electrophoretic analysis. Patients Nos. 1 to 8 suffered from unexplained biliary cirrhosis as defined in the accompanying report (1). Patient No. 9 was a normal young adult. Patients Nos. 10 and 11 had severe post-necrotic cirrhosis proven by autopsy. Their sera were included in this study for contrast because of a marked reduction in total lipid. Table I lists the 11 patients according to the total lipid concentration in the serum.

Electrophoretic analyses were carried out by the method of Longsworth (3). The sera were dialyzed against barbital buffer $(\mathrm{pH}, 8.6 ; \mathrm{u}, 0.1)$. Mobilities were calculated from the formula $U=\frac{h k_{p} A}{I t}$ (4). Ascending patterns were used for the calculations of the beta globulin areas because of the interference in the descending patterns by the beta globulin disturbance. Serum was used in order to avoid the fibrinogen peak. Calculations of the areas in the electrophoretic patterns were expressed as per cent of the total area. This leads to some error in estimating beta globulin because of variations in albumin and gamma globulin. However, in each of the sera used the rise in the gamma globulin was approximately equal to the fall in albumin, thus minimizing the error in beta globulin variations. The observations of Armstrong, Budka, Morrison and Hasson (5) on the refractive index increments of various fractions of serum prepared by alcoholic fractionation furnish information that is helpful in calculating the amount of beta globulin directly from the electrophoretic pattern. Such estimations were attempted, utilizing the factor $1.71 \times 10^{-4}$. However, because of the unknown composition of the beta globulin peaks in these abnormal sera, the beta globulin was expressed simply in terms of absolute units of area. This could be used only for comparing the different sera but served as a check of the validity of expressing the area in terms of percentage of the total. Total protein nitrogen was determined for all of the sera by micro-Kjeldahl analysis.

In experiments on the effect of removal of lipids, serum was diluted six times with a solution containing $1 \%$ liquid phenol and $12 \% \mathrm{NaCl}(6)$. This was not an extraction procedure but simply one which appeared to interfere with the stabilizing effect of lecithin on the serum lipids. Similar effects were obtained with the enzyme lecithinase. The mixture was allowed to stand for 24 hours at $0^{\circ} \mathrm{C}$. The lipid was then centrifuged into a pellicle at the surface at 10,000 r.p.m. Not all sera permitted the formation of a pellicle with a clear subnatant solution. These were discarded. The pellicle was washed and extracted with Bloor's alcohol-ether mixture. Cholesterol, phospholipid and total lipid were determined on this extract. Nitrogen analysis was carried out on the material remaining after alcohol-ether extraction. Electrophoretic patterns were made on the subnatant solution after bringing the material to the original volume of the serum in a dialysis bag in front of an electric fan and dialyzing against the standard buffer solution.

Total lipid, cholesterol, and phospholipid determinations were obtained on the same sera that were studied electrophoretically. The methods are described separatedly (1).

\section{RESULTS}

The characteristic feature of the electrophoretic pattern in the high-lipid sera of the patients with biliary cirrhosis was a rise in the beta globulin component. In addition, albumin was slightly reduced and the gamma globulin was elevated. Figure 1 illustrates the ascending and descending patterns from the sera of two of the patients with high total lipid concentrations. Patient No. 2, with a total lipid of $2489 \mathrm{mg} . \%$ in the serum, 

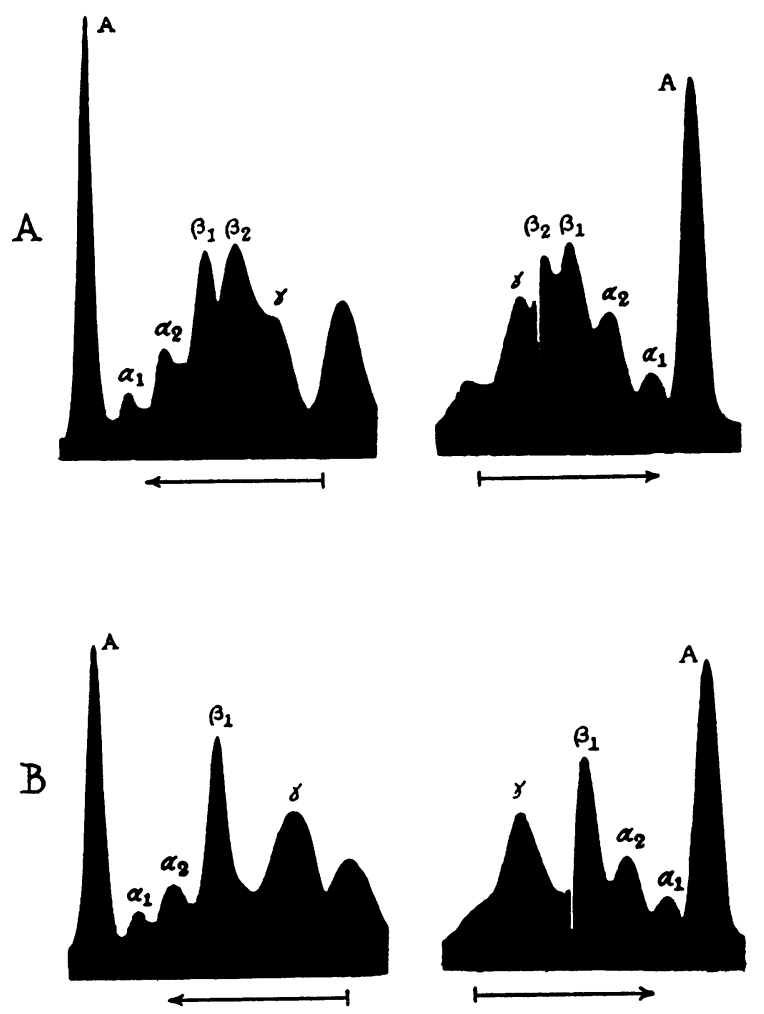

Fig. 1. Ascending and Descending Electrophoretic Patterns from Two of the Patients Showing Elevated Serum Lipids

A-patient No. 2; total lipid, 2489 mg.\%. B-patient No. 7; total lipid, $1317 \mathrm{mg} . \%$ The increase in beta globulin is readily apparent.

showed an extremely large area representing beta and beta $_{2}$ globulins. Patient No. 7, with a somewhat lower lipid level, also showed a very large beta globulin area but considerably smaller than the combined beta b $_{1}$ and beta of $_{2}$ patient No. 2 . Figure 3 illustrates the pattern of the serum from two other patients with total lipid concentrations above $2000 \mathrm{mg} . \%$.

In each case the area represented by the beta globulin peaks was proportional to the total lipid concentration of the serum. Figure 2 illustrates the direct relationship between these two variables in the serum of the 11 patients studied. The beta globulin percentages in this figure represent the sum of the various beta globulin peaks. A line drawn through the points extrapolates to zero. For every $1000 \mathrm{mg} . \%$ rise in total lipid, there was approximately a $20 \%$ increase in beta globulin area. Expression of the beta globulin in absolute units of area instead of percentage of the total showed a similar straight line relationship when plotted against total lipid concentration. This line also passed through the zero point.

Table I contains the values for various lipid fractions along with the electrophoretic components for all of the sera covering a broad range of lipid concentration. In addition to the expression of the electrophoretic fractions as percentages of the total, the sum of the beta globulin components for each of the sera is presented in absolute terms as a multiple of the beta globulin area of normal serum. The predominant abnormality in the lipid pattern was an increase in phospholipid, although the free cholesterol and neutral fat were also increased. It was not possible to determine whether any one lipid fraction influenced the beta globulin area more than the others. The alpha globulins did not show an increase in the high-lipid sera similar to that observed for the beta globulins. However, if the alpha globulins were determined on the basis of the actual area present rather than as a percentage of the total, it was found that a definite rise did occur in the high lipid sera. The very large alpha ${ }_{2}$ peaks

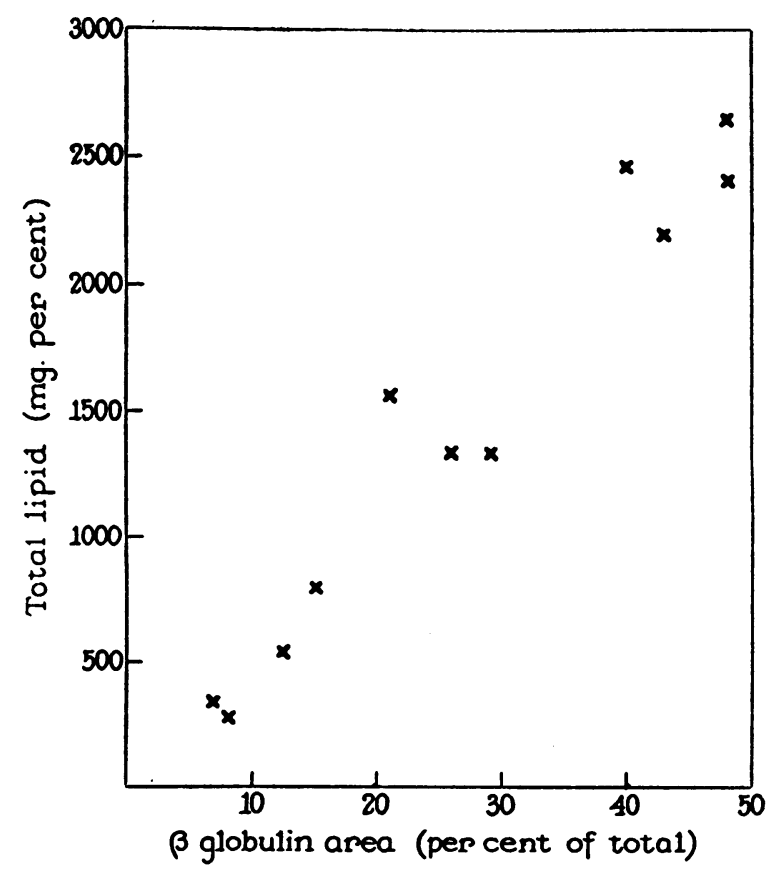

Fig. 2. The Relationship. Between the Total Lipid Concentration and the Electrophoretically Determined Beta Globulin Area for the Sera of the 11 Patients Studied 
TABLE I

The lipid and electrophoretic composition of the sera of the 11 patients studied

\begin{tabular}{|c|c|c|c|c|c|c|c|c|c|c|c|c|c|}
\hline \multirow{2}{*}{$\begin{array}{l}\text { Patient } \\
\text { No. }\end{array}$} & \multirow{2}{*}{ Disease } & \multicolumn{5}{|c|}{ Lipid mg. \% } & \multicolumn{6}{|c|}{$\begin{array}{l}\text { Electrophoretic area } \\
\% \text { of total }\end{array}$} & \multirow[t]{2}{*}{$\frac{\beta \text { globulin area }}{\text { Normal } \boldsymbol{\beta} \text { globulin areat }}$} \\
\hline & & $\begin{array}{l}\text { Total } \\
\text { lipid }\end{array}$ & $\begin{array}{l}\text { Phospho- } \\
\text { lipid }\end{array}$ & $\mathrm{fat}_{\text {fat }}^{\text {Neutal }}$ & $\begin{array}{l}\text { Total } \\
\text { choles- } \\
\text { terol }\end{array}$ & $\begin{array}{l}\text { Free } \\
\text { choles- } \\
\text { terol }\end{array}$ & Alb. & $\boldsymbol{\alpha}_{\mathbf{1}}$ & $\boldsymbol{\alpha}_{\mathbf{s}}$ & $\boldsymbol{\beta}_{\mathbf{1}}$ & $\beta_{2}$ & $\boldsymbol{\gamma}$ & \\
\hline $\begin{array}{r}1 \\
2 \\
3 \\
4 \\
5 \\
6 \\
7 \\
8 \\
9 \\
10\end{array}$ & $\begin{array}{l}\text { Biliary cirrhosis } \\
\text { Biliary cirrhosis } \\
\text { Biliary cirrhosis } \\
\text { Biliary cirrhosis } \\
\text { Biliary cirrhosis } \\
\text { Biliary cirrhosis } \\
\text { Biliary cirrhosis } \\
\text { Biliary cirrhosis } \\
\text { Normal } \\
\text { Post-necrotic }\end{array}$ & $\begin{array}{l}2650 \\
2489 \\
2400 \\
2200 \\
1560 \\
1340 \\
1317 \\
811 \\
584 \\
323\end{array}$ & $\begin{array}{r}1300 \\
1047 \\
1220 \\
980 \\
620 \\
594 \\
553 \\
310 \\
183 \\
110\end{array}$ & $\begin{array}{r}348 \\
527 \\
293 \\
451 \\
327 \\
216 \\
123 \\
116 \\
124 \\
66\end{array}$ & $\begin{array}{l}950 \\
853 \\
810 \\
732 \\
453 \\
417 \\
492 \\
281 \\
191 \\
103\end{array}$ & $\begin{array}{r}864 \\
750 \\
682 \\
671 \\
186 \\
229 \\
244 \\
107 \\
48 \\
30\end{array}$ & $\begin{array}{l}29 \\
26 \\
27 \\
26 \\
35 \\
36 \\
28 \\
47 \\
63 \\
43\end{array}$ & $\begin{array}{l}2 \\
4 \\
3 \\
5 \\
6 \\
3 \\
4 \\
5 \\
4 \\
6\end{array}$ & $\begin{array}{r}5 \\
11 \\
9 \\
9 \\
11 \\
10 \\
9 \\
10 \\
8 \\
12\end{array}$ & $\begin{array}{l}22 \\
16 \\
20 \\
43 \\
21^{*} \\
27 \\
29 \\
17 \\
13 \\
7\end{array}$ & $\begin{array}{l}26 \\
25 \\
28\end{array}$ & $\begin{array}{l}16 \\
18 \\
13 \\
17 \\
27 \\
24 \\
30 \\
21 \\
12 \\
32\end{array}$ & $\begin{array}{l}6.0 \\
5.1 \\
5.8 \\
4.9 \\
2.5 \\
2.3 \\
2.6 \\
1.7 \\
1.0 \\
0.5\end{array}$ \\
\hline 11 & $\begin{array}{l}\text { Post-necrotic } \\
\text { cirrhosis }\end{array}$ & 296 & 120 & 91 & 72 & 51 & 41 & 5 & 7 & 8 & & 39 & 0.5 \\
\hline
\end{tabular}

* $\beta_{1}$ for this serum represents the sum of $\beta_{1}^{\prime}$ and $\beta_{1}$.

$\dagger$ The absolute $\beta$ globulin area of normal serum No. 9 was used for this comparison.

reported by others (7) in nephrosis were not observed.

In the four sera with a total lipid concentration above $2000 \mathrm{mg} . \%$, three showed a double beta globulin peak. The lipid composition of these four sera was very similar, as was the composition of the proteins. The reason for the single peak in the one case and the double peaks in the other three was not apparent. Table II shows the results of determinations of the mobility of the various beta globulin components. The component designated beta $a_{1}$ had the mobility of the beta globulin seen in normal serum. The concentration of this component was increased in all of the highlipid sera. The component beta ${ }_{2}$ showed a much

TABLE II

Mobilities of the various $\beta$ globulin peaks encountered in the sera of the 11 patients studied

\begin{tabular}{c|c|c|c}
\hline \hline & \multicolumn{3}{|c}{ Mobilities $\times 105$} \\
\cline { 2 - 4 } Patient No. & $\beta_{1}^{\prime}$ & $\beta_{1}$ & $\beta_{2}$ \\
\cline { 2 - 4 } & & 2.73 & 1.93 \\
2 & & 2.90 & 2.00 \\
3 & & 2.86 & 1.97 \\
4 & & 2.90 & \\
5 & 3.2 & 2.80 & \\
6 & & 3.05 & \\
7 & & 2.84 & \\
8 & & 2.80 & \\
9 & & 3.10 & \\
10 & & 2.80 & \\
11 & & 2.95 & \\
\hline
\end{tabular}

slower mobility and was seen only in the very high-lipid sera. Another component, beta prime ${ }_{1}$, with unusually rapid mobility was observed in only one of the sera (patient No. 5).

In order to determine the effect of lipid removal on the electrophoretic pattern of the high-lipid sera, electrophoretic patterns were carried out before and after diluting serum with a high salt $1 \%$ phenol solution. This procedure has been demonstrated to cause 85 to $95 \%$ of the lipid of the serum to separate from the solution along with

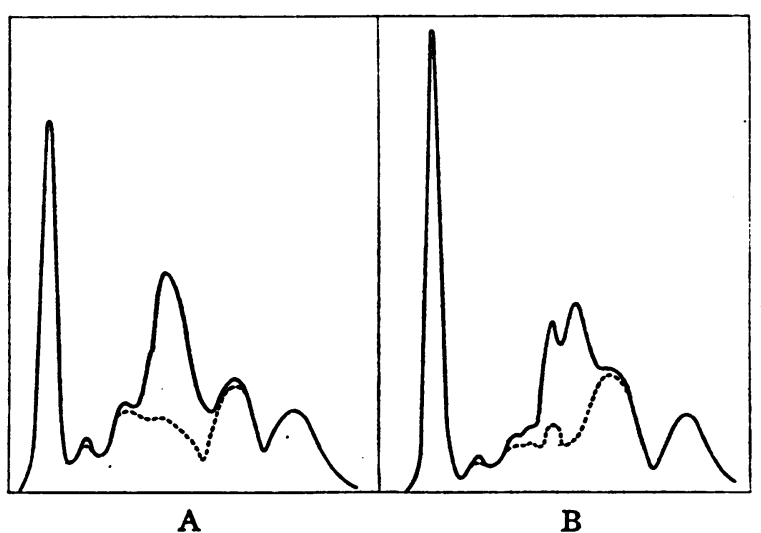

Fig. 3. Ascending Electrophoretic Patterns from Two High-Lipid Sera Before and After Separation of 95\% of the Serum Lipids by Dilute Phenol SoluTION

Dotted lines represent the areas obtained by the procedure 
approximately $5 \%$ of the protein (6). Figure 3 illustrates these patterns from two of the sera. The procedure did not alter significantly the albumin and gamma globulin components. However, the beta globulin area was reduced markedly. In Figure 3A the total protein nitrogen of the serum was $1.07 \%$; $0.06 \mathrm{gm} . \%$ protein nitrogen was removed on centrifugation. The total lipid of this serum was $2200 \mathrm{mg} . \%$; $2070 \mathrm{mg} . \%$ were removed on centrifugation. The electrophoretic area lost by the procedure represented $33 \%$ of the original total area. The nitrogen-lipid ratio for the area lost could be calculated readily. The factor that should be used for the conversion of nitrogen to lipoprotein for the area lost is not clear because it probably represents various lipoproteins. If the ordinary protein factor 6.25 is used, the area lost represents $17 \%$ protein. Similarly, for Figure 3B, the area lost represents $14 \%$ protein. This would indicate a lipid content of $83 \%$ and $86 \%$ for the areas lost.

Numerous other analyses of the amount of protein which separated with lipid by the high salt $1 \%$ phenol procedure indicated that the composition of the separated material averaged $14 \%$ protein and $86 \%$ lipid. These observations have been published separately (6). Sera from normal individuals showed a higher protein content of the separated material. The average value obtained was $28 \%$ protein. These results suggest that the elevation in total lipid in the patients under discussion in this study was not associated with a proportional increase in tightly bound lipid-protein complexes.

\section{DISCUSSION}

The electrophoretic determinations on the sera of the 11 patients included in this study indicate that the beta globulin area is the primary component which is increased with increasing lipid concentrations. The alpha globulin showed minor changes. The direct correlation of total lipid and total beta globulin area was striking and suggests that the concentration of beta globulins and lipoproteins in serum is determined by the total lipid level.

Just how the lipoproteins which make up the beta globulin area in the high-lipid sera differ from those normally present in serum is not entirely clear. Two differences, however, have been noted.
First, the amount of protein tightly bound to lipid was not elevated to the degree expected from the total lipid increase. Secondly, a slowly moving component, beta ${ }_{2}$, appeared in the electrophoretic patterns of three of four sera containing more than $2000 \mathrm{mg} . \%$ total lipid. This component contained a large part of the total lipid of the serum. The possibility is raised that another protein takes over the function of combining with the large excess of lipid in these sera, particularly since the normal beta $_{1}$ component is markedly increased. Whether this represents a new protein or increased amounts of a protein present in normal serum is not clear.

The slowly moving beta ${ }_{2}$ component showed approximately the same mobility as fibrinogen. The fact that this peak did not represent fibrinogen was verified by determination of fibrinogen levels in the plasma of these patients. Although a slight elevation was found, this was not nearly sufficient to cause the marked beta ${ }_{2}$ peaks. In addition, since serum was used for the electrophoretic analyses, the major portion of the fibrinogen had been removed.

In the presence of high-lipid concentration the error involved in the usual calculation of various protein fractions from electrophoretic patterns as percentage of the total area is apparent from these studies. In the one illustration shown, $48 \%$ of the total electrophoretic area represented beta globulin but this contained only a small percentage of the total protein nitrogen. Similar conclusions have been reached by other observers who extracted the lipids of serum with ether or acetone in the cold $(7,8)$. Accurate estimation of protein concentration in high-lipid sera such as those from patients with biliary cirrhosis and nephrosis can only be obtained by direct calculation from the refractive index increment of the proteins.

\section{SUMMARY}

1. Electrophoretic patterns of the sera of patients with unexplained biliary cirrhosis containing high-lipid concentration showed marked increases in the beta globulin components.

2 . The total beta globulin area was directly proportional to the total lipid concentration of the serum. Determinations were carried out over a total lipid range from 300 to $2700 \mathrm{mg} . \%$.

3. The high-lipid sera all showed a beta globulin 
component with a mobility close to that of the beta globulin seen in normal serum. An additional component with a slower mobility appeared in three of the four sera with very high lipid concentration.

4. Attempts were made to determine the composition of the beta globulins by means of electrophoretic patterns before and after separation of the lipids from serum.

\section{ACKNOWLEDGMENT}

The authors are indebted to Dr. G. E. Perlman for valuable aid in the electrophoretic analyses and to $\mathrm{Dr}$. L. G. Longsworth and Dr. D. A. MacInnes for making available the electrophoretic equipment.

\section{BIBLIOGRAPHY}

1. Ahrens, E. H., Jr., and Kunkel, H. G., The relationship between serum lipids and skin xanthomata in 18 patients with primary biliary cirrhosis. J. Clin. Invest., 1949, 28, 1565.
2. Ahrens, E. H., Jr., and Kunkel, H. G., The stabilization of serum lipid emulsions by serum phospholipids. J. Exper. Med., 1949, 90, 409.

3. Longsworth, L. G., Recent advances in the study of proteins by electrophoresis. Chem. Rev., 1942, 30, 323.

4. Longsworth, L. G., Shedlovsky, T., and MacInnes, D. A., Electrophoretic patterns of normal and pathological human blood serum and plasma. J. Exper. Med., 1939, 70, 399.

5. Armstrong, S. H., Budka, M. J. E., Morrison, K. C., and Hasson, M., Preparation and properties of serum and plasma proteins. XII. The refractive properties of the proteins of human plasma and certain purified fractions. J. Am. Chem. Soc., 1947, 69, 1747.

6. Kunkel, H. G., and Ahrens, E. H., Jr., Estimation of total lipid concentration in serum by a rapid turbidimetric procedure. To be published.

7. Longsworth, L. G., and MacInnes, D. A., An electrophoretic study of nephrotic sera and urine. J. Exper. Med., 1940, 71, 77.

8. Zeldis, L. J., Alling, E. L., McCoord, A. B., and Kulka, J. P., Plasma protein metabolism, electrophoretic studies. J. Exper. Med., 1945, 82, 411. 